\title{
Influences of Beta-Alanine and L-Histidine Supplementation on Growth Performance, Meat Quality, Carnosine Content, and mRNA Expression of Carnosine-Related Enzymes in Broilers
}

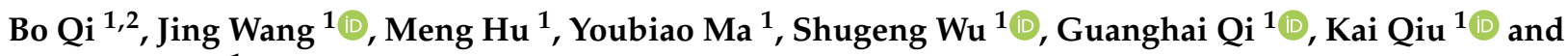 \\ Haijun Zhang ${ }^{1, *}$
}

1 Key Laboratory of Feed Biotechnology, Ministry of Agriculture and Rural Affairs, National Engineering Research Center of Biological Feed, Feed Research Institute, Chinese Academy of Agricultural Sciences, Beijing 100081, China; bo.qi@live.vu.edu.au (B.Q.); wangjing@caas.cn (J.W.); 18511602275@163.com (M.H.); myb0514@126.com (Y.M.); wushugeng@caas.cn (S.W.); qiguanghai@caas.cn (G.Q.); qiukai@caas.cn (K.Q.)

2 College of Health and Biomedicine, Victoria University, Footscray, Victoria 3011, Australia

* Correspondence: zhanghaijun@caas.cn; Tel.: +86-138-1136-4279

Citation: Qi, B.; Wang, J.; Hu, M.; Ma, Y.; Wu, S.; Qi, G.; Qiu, K.; Zhang, $H$. Influences of Beta-Alanine and L-Histidine Supplementation on Growth Performance, Meat Quality, Carnosine Content, and mRNA Expression of Carnosine-Related Enzymes in Broilers. Animals 2021, 11, 2265. https://doi.org/10.3390/ ani11082265

Academic Editors: Giuseppe Martino and Ianni Andrea

Received: 15 July 2021

Accepted: 26 July 2021

Published: 31 July 2021

Publisher's Note: MDPI stays neutral with regard to jurisdictional claims in published maps and institutional affiliations.

Copyright: (c) 2021 by the authors. Licensee MDPI, Basel, Switzerland. This article is an open access article distributed under the terms and conditions of the Creative Commons Attribution (CC BY) license (https:// creativecommons.org/licenses/by/ $4.0 /)$.
Simple Summary: In recent years, much attention has been paid to developing functional meat, which contains more functional peptides to impart health benefits. Poultry meat is a good source of imidazole dipeptides (carnosine and its derivative anserine), which are active endogenous constituents and may convey versatile physiological functions to promote health conditions. Carnosine is synthesized from L-histidine and beta-alanine. Dietary addition of histidine and/or beta-alanine may elevate the carnosine content in broiler meat. The current study further investigated the interaction of L-histidine and beta-alanine supplementation on carnosine content, meat quality, and gene expression of carnosine-related enzymes in broilers, which can facilitate a better understanding of the relationship between L-histidine and beta-alanine in carnosine synthesis.

Abstract: The current study investigated the effect of dietary L-histidine and beta-alanine supplementation on growth performance, meat quality, carnosine content, and gene expression of carnosine-related enzymes in broilers. A two-factor design was adopted in this study. A total of 640 1-day-old male broilers were assigned to eight treatments with factorial arrangement containing four levels of L-histidine $(0,650,1300$, or $1950 \mathrm{mg} / \mathrm{kg})$ and two levels of beta-alanine ( 0 or $1200 \mathrm{mg} / \mathrm{kg})$ supplementation; $0 \mathrm{mg} / \mathrm{kg}$ histidine and $/$ or $0 \mathrm{mg} / \mathrm{kg}$ were treated as control groups. Each treatment including eight replicates with 10 birds each and the feeding trial lasted for 42 days. Dietary supplementation with L-histidine and beta-alanine did not affect average daily gain (ADG), average daily feed intake (ADFI), and feed conversion ratio (FCR) of broilers during the grower (22-42 days) and the entire phase (1-42 days), compared with the control group $(p>0.05)$. The only exception was a significantly reduced ADG in the $1950 \mathrm{mg} / \mathrm{kg}$ L-histidine group in the starter period (1-21 days, $p<0.05)$. L-Histidine at $1950 \mathrm{mg} / \mathrm{kg}$ significantly decreased redness $\left(\mathrm{a}^{*}\right)$ and yellowness $\left(\mathrm{b}^{*}\right)$ values of the meat at $45 \mathrm{~min}$ postmortem $(p<0.05)$, whereas it increased $\mathrm{b}^{*}$ value and $\mathrm{pH}$ in breast muscle at $24 \mathrm{~h}$ postmortem. Moreover, dietary supplementation with beta-alanine alone or combination with L-histidine significantly increased $\Delta \mathrm{pH}$ in breast muscle $(p<0.01)$. Dietary L-histidine markedly increased total superoxide dismutase activity and total antioxidant capacity (T-AOC) both in breast muscle $(p<0.01)$ and in plasma $(p<0.01)$, and it decreased malondialdehyde (MDA) concentration in breast muscle $(p<0.01)$. Dietary addition of beta-alanine, alone or combination, significantly increased T-AOC in breast muscle $(p<0.01)$ and markedly decreased MDA content both in breast muscle and in plasma $(p<0.01)$. Addition of L-histidine and beta-alanine significantly increased muscle peptide (carnosine and anserine) content $(p<0.05)$ and upregulated the expression of carnosine synthase, transporter of carnosine/ L-histidine, and L-histidine decarboxylase genes $(p<0.05)$, with greater change occurring in the combination group of $1300 \mathrm{mg} / \mathrm{kg}$ L-histidine and $1200 \mathrm{mg} / \mathrm{kg}$ beta-alanine. Overall, dietary L-histidine and beta-alanine could improve meat quality and antioxidant capacity, enhance the carnosine and anserine content, and upregulate the gene expression of carnosine synthesis-related enzymes in broilers. 
Keywords: beta-alanine; broiler; dipeptide; L-histidine; mRNA expression

\section{Introduction}

Concurrent with increased social development and improved living standards, the improvement of diet composition has become a key factor to improve the health status and welfare of animals, as well as to enhance productivity in livestock [1] and performance in athletic species [2]. Today, there is a worldwide attempt to reduce antibiotic use in poultry production, which has caused increased microbial resistance to antibiotics and residues in animal products that can be harmful to consumers. Carnosine and anserine have antioxidation and antiaging properties, including better maintenance of muscle strength and $\mathrm{pH}$ buffering properties, which play an important role in stability, fatigue resistance, etc. [3]. Therefore, the development of improved and functional meat products (e.g., with elevated carnosine) may provide lifelong benefits and improve global health outcomes in aging populations. Carnosine is predominantly found in skeletal muscles and brain tissues $[4,5]$ and is synthesized from L-histidine and beta-alanine by carnosine synthetase [6]. The concentration of carnosine is influenced by different factors such as animal species, sex, age, muscle fiber type, dietary composition and feeding methods (watering or feeding directly), and management [7-11].

Supplementation with $1 \mathrm{~g}$ L-histidine $/ \mathrm{kg}$ of feed could elevates carnosine and anserine in chicken breast muscle by $64 \%$ and $10 \%$, respectively [11]. Dietary addition of $22 \mathrm{mmol} / \mathrm{kg}$ (about $1.960 \mathrm{~g} / \mathrm{kg}$ ) beta-alanine increased carnosine content by $67 \%$ in chicken meat [12]. Moreover, dietary supplementation with histidine alone or with beta-alanine may increase carnosine concentrations of breast muscle [13]. A study in our laboratory showed that a supplemented diet of $1196 \mathrm{mg} / \mathrm{kg}$ beta-alanine produced the highest carnosine content in breast muscle in broilers, significantly improved the growth performance, and increased the gene expression of the carnosine synthetase and taurine transporter (a beta-alanine transporter) in breast muscle in broilers [14]. A previous study found similar results in mice with beta-alanine supplementation, which increased the expression of carnosine synthetase and taurine transporter gene [6]. However, knowledge on the effect of the interaction of histidine alone or combination with beta-alanine on the gene expression of carnosine-related enzymes is limited in broilers. Therefore, the main purpose of the current study was to explore the interaction of dietary fortification with L-histidine and beta-alanine on growth performance, meat quality, carnosine level, and gene expression of carnosine-related enzymes in broilers.

\section{Materials and Methods}

All experimental procedures were reviewed and approved by the Animal Care and Use Committee of the Feed Research Institute of the Chinese Academy of Agricultural Sciences (FRI-CAAS20181112).

\subsection{Diets and Design of Experiment}

A total of 640 1-day-old male Arbor Acre broilers were assigned to eight treatment groups with factorial arrangement containing four levels of L-histidine supplementation $(0,650,1300$, or $1950 \mathrm{mg} / \mathrm{kg})$ and two levels of beta-alanine $(0$ or $1200 \mathrm{mg} / \mathrm{kg})$. Each treatment consisted of eight replicates with 10 birds. All birds were raised in a battery cage (length $\times$ depth $\times$ height: $1.3 \mathrm{~m} \times 0.7 \mathrm{~m} \times 0.5 \mathrm{~m}$ ) in an environmentally controlled room with continuous incandescent white light throughout the experiment. The room temperature was set to $33^{\circ} \mathrm{C}$ for the first 3 days, and then the temperature dropped by $2{ }^{\circ} \mathrm{C}$ each successive week until it settled at $24^{\circ} \mathrm{C}$. Chicks had free access to feed and fresh water during the entire feeding trial. The composition of the experimental diet and the nutrient levels are presented in Table 1. All chickens were raised in accordance with the regulations of the Arbor Acre Broiler Commercial Management Guide [15]. 
Table 1. Composition of the experimental diet and the nutrient levels (air-dried basis, \%).

\begin{tabular}{|c|c|c|}
\hline Item & Starter Period (1-21 Days) & Grower Period (22-42 Days) \\
\hline \multicolumn{3}{|l|}{ Components, $\%$} \\
\hline Corn & 59.22 & 62.20 \\
\hline Soybean meal (47\%) & 34.37 & 30.84 \\
\hline Vegetable oil & 2.27 & 3.26 \\
\hline Dicalcium phosphate & 1.82 & 1.55 \\
\hline Limestone & 1.31 & 1.23 \\
\hline Salt & 0.30 & 0.30 \\
\hline DL-Methionine (98\%) & 0.24 & 0.19 \\
\hline L-Lysine- $\mathrm{HCl}(78 \%)$ & 0.09 & 0.07 \\
\hline L-Threonine (98) & 0.06 & 0.04 \\
\hline Vitamin premix ${ }^{1}$ & 0.02 & 0.02 \\
\hline Mineral premix ${ }^{2}$ & 0.20 & 0.20 \\
\hline Choline chloride (50 \%) & 0.10 & 0.10 \\
\hline Total & 100 & 100 \\
\hline \multicolumn{3}{|l|}{ Calculated nutrient levels } \\
\hline $\mathrm{AME}, \mathrm{MJ} / \mathrm{kg}$ & 12.35 & 12.77 \\
\hline Crude protein, $\%$ & 21.5 & 20.00 \\
\hline Calcium, \% & 1.00 & 0.90 \\
\hline Total phosphorus, $\%$ & 0.69 & 0.63 \\
\hline Available phosphorus, $\%$ & 0.45 & 0.40 \\
\hline Lysine, $\%$ & 1.21 & 1.10 \\
\hline Methionine, \% & 0.55 & 0.48 \\
\hline Methionine + cysteine, $\%$ & 0.88 & 0.80 \\
\hline Threonine, $\%$ & 0.86 & 0.78 \\
\hline
\end{tabular}

${ }^{1}$ The vitamin premix supplied the following per $\mathrm{kg}$ of complete feed: vitamin $\mathrm{A}, 12,500 \mathrm{IU}$; vitamin $\mathrm{D}_{3}, 2500 \mathrm{IU}$; vitamin $\mathrm{K}_{3}, 2.65 \mathrm{mg}$; vitamin $\mathrm{B}_{1}, 2 \mathrm{mg}$; vitamin $\mathrm{B}_{2}, 6 \mathrm{mg}$; vitamin $\mathrm{B}_{12}, 0.025 \mathrm{mg}$; vitamin $\mathrm{E}, 30 \mathrm{IU}$. ${ }^{2}$ The mineral premix supplied the following per $\mathrm{kg}$ of complete feed: $\mathrm{Cu}, 8 \mathrm{mg}$; Zn, $75 \mathrm{mg} ; \mathrm{Fe}, 80 \mathrm{mg}$; Mn, $100 \mathrm{mg}$; Se, $0.15 \mathrm{mg}$; I, $0.35 \mathrm{mg}$; biotin, $0.0325 \mathrm{mg}$; folic acid, $1.25 \mathrm{mg}$; pantothenic acid, $12 \mathrm{mg}$; niacin, $50 \mathrm{mg}$.

\subsection{Growth Performance}

Body weight (BW) and feed intake were recorded during the starter phase (1 to 21 days), the grower phase (22 to 42 days), and the entire phase (1 to 42 days). ADG, ADFI, and FCR were calculated. On days 21 and 42, two birds at average BW from each replicate group were fasted for $12 \mathrm{~h}$, weighed, and exsanguinated. Blood samples were collected (between 8:00 and 9:00 a.m. on trial day) in heparinized centrifuge tubes during bleeding from the left jugular vein and then immediately centrifuged at $1800 \times \mathrm{g}$ for $15 \mathrm{~min}$ at $4{ }^{\circ} \mathrm{C}$. The plasma samples were stored at $-20^{\circ} \mathrm{C}$ until analysis. The right side of breast muscle was subsequently removed to determine meat color and muscle $\mathrm{pH}$. All samples were stored at $4{ }^{\circ} \mathrm{C}$ until analysis.

\subsection{Meat Quality}

\subsection{1. $\mathrm{pH}$ and Meat Color}

Muscle $\mathrm{pH}$ values at $45 \mathrm{~min}\left(\mathrm{pH}_{45} \mathrm{~min}\right)$ and $24 \mathrm{~h}\left(\mathrm{pH}_{24} \mathrm{~h}\right)$ postmortem were determined using a calibrated electronic $\mathrm{pH}$ meter (CyberScan $\mathrm{pH}$ 310, Eutech Instruments Pte. Ltd., Singapore). Each sample was measured in triplicate at different positions within the muscle, and the average value was calculated as the result. The value of $\mathrm{pH}$ decline within $24 \mathrm{~h}$ postmortem $(\Delta \mathrm{pH})$ was calculated as $\Delta \mathrm{pH}=\mathrm{pH}_{24 \mathrm{~h}}-\mathrm{pH}_{45}$ min. At $24 \mathrm{~h}$ after slaughter, meat color was measured in duplicate using a Chroma Meter (Chroma Meter WSC-S, Shanghai Precision and Scientific Instrument Co., Shanghai, China). Color was reported according to the CIE-Lab trichromatic system as lightness $\left(\mathrm{L}^{*}\right)$, redness $\left(\mathrm{a}^{*}\right)$, and yellowness $\left(b^{*}\right)$ values [16].

\subsubsection{Drip Loss}

Right pectoralis muscles, which were trimmed into regular-shaped fillets $(30 \pm 1.5 \mathrm{~g}$, wet weight, $\mathrm{W}_{1}$ ), were placed in a zip-sealed plastic bag and then filled with liquid nitrogen 
to avoid oxidation, evaporation, and mutual extrusion. All bags were stored at $4{ }^{\circ} \mathrm{C}$ for $24 \mathrm{~h}$ and reweighed $\left(\mathrm{W}_{2}\right)$. Drip loss was calculated as $(\%)=\left(\mathrm{W}_{1}-\mathrm{W}_{2}\right) / \mathrm{W}_{1} \times 100 \%(\mathrm{ZHANG}$ 2009).

\subsubsection{Cooking Loss}

After the drip loss, the samples remained in storage at $4{ }^{\circ} \mathrm{C}$ until $72 \mathrm{~h}$ postmortem. At $72 \mathrm{~h}$ postmortem, samples were removed, the water was wiped off the surface, and samples were weighed once more $\left(\mathrm{W}_{3}\right)$. Next, the samples were placed in zip-sealed polyethylene bags and heated in a water bath at $85^{\circ} \mathrm{C}$ for $20 \mathrm{~min}$, cooled under running water to ambient temperature, dried, and weighed $\left(\mathrm{W}_{4}\right)$. Cooking loss was calculated as $(\%)=\mathrm{W}_{3}-\mathrm{W}_{4} / \mathrm{W}_{3}$ $\times 100 \%(X U 2011)$.

\subsubsection{Shear Force}

After measuring the cooking loss, the samples were stored at $4{ }^{\circ} \mathrm{C}$ until $96 \mathrm{~h}$ postmortem and then used for measuring the shear force value. Each sample was trimmed into three stripes (length $\times$ depth $\times$ height: $2 \mathrm{~cm} \times 1 \mathrm{~cm} \times 1 \mathrm{~cm}$ ), each sample was cut three times at different locations, and the final results were expressed as the average value of nine cuts.

\subsection{Antioxidant Indices in Breast Muscle and Plasma}

About $0.5 \mathrm{~g}$ of frozen muscle was cut and homogenized for 2 min with $4.5 \mathrm{~mL}$ of $0.9 \%$ iced saline and then centrifuged at $3500 \times g$ for $10 \mathrm{~min}$ at $4{ }^{\circ} \mathrm{C}$. The supernatant was collected and divided into small tubes and stored at $-20^{\circ} \mathrm{C}$ for analyzing antioxidant parameters, which included total superoxide dismutase (T-SOD) activity, total antioxidant capacity (T-AOC), and malondialdehyde (MDA) content. All parameters mentioned above were analyzed in muscle and plasma using standard commercial kits (Nanjing Jiancheng Bioengineering Institute, Nanjing, China) and a molecular microplate reader (Molecular Device LLC., San Jose, CA, USA). Each sample was measured in triplicate.

\subsection{Dipeptide Content in Breast and Gene Expression of Carnosine Synthesis-Related Enzymes}

\subsubsection{Dipeptide Content}

The contents of carnosine and anserine were determined using an A300 automatic amino-acid analyzer (Membra Pure, Bodenheim, Germany). Samples were combined with $200 \mu \mathrm{L}$ of sulfosalicylic acid $(10 \%)$ to precipitate proteins kept at $4{ }^{\circ} \mathrm{C}$ for $1 \mathrm{~h}$, and then centrifuged at $14,500 \times g$ for $15 \mathrm{~min}$. The supernatant was filtered via a $0.45 \mu \mathrm{m}$ pore size filter membrane after proper dilution (Millipore Co., Bedford, MA) and then directly injected into the analyzer for free amino-acid measurement. Next, $20 \mu \mathrm{L}$ of ninhydrin, used as a trimethylbenzene substrate, was injected into the analyzer at $0.09 \mathrm{~mL} / \mathrm{min}$ flow rate. Detection was performed by UV absorbance at wavelengths of 570/440 nm used for detection.

\subsubsection{Total RNA Extraction and cDNA Synthesis}

Breast muscle tissues were homogenized with Trizol Reagent (Invitrogen, Carlsbad, CA, USA), and total RNA was extracted conforming to the manufacturer's manual. The concentrations of RNA samples were quantified using the NanoDrop ND 1000 spectrophotometer (Thermo Fisher Scientific, Waltham, MA, USA). Total RNA (about $1 \mathrm{mg}$ ) extracted from each sample was utilized to synthesize the first-strand cDNA using the TIANGEN Quantscript RT kit, following the manufacturer's instructions (TIANGEN Biotech Co. Ltd., Beijing, China). Procedures for RNA preparation conformed to the Minimum Information for Publication of Quantitative Real-Time (RT) PCR Experiments guidelines.

\subsubsection{Quantitative of Gene Expression}

Gene expression of carnosine synthase (CARNS), carnosinase (CNDP2), carnosine/Lhistidine transporters (PHT1), proton-coupled oligopeptide transporters (PEPT1, PEPT2), 
and L-histidine decarboxylase (HDC) was determined using a RT PCR kit according to the manufacturer's instructions (Real MasterMix-SYBR Green; TIANGEN, China). Reactions of RT quantitative PCR were performed using an i-Cycler iQ5 multicolor RT PCR detection system (Bio-Rad, CA, USA), and the protocol used was as follows: $95^{\circ} \mathrm{C}$ for $5 \mathrm{~min} ; 40$ cycles of $95^{\circ} \mathrm{C}$ for $10 \mathrm{~s}, 60^{\circ} \mathrm{C}$ for $30 \mathrm{~s}$, and $72{ }^{\circ} \mathrm{C}$ for $30 \mathrm{~s}$; final extension at $72{ }^{\circ} \mathrm{C}$ for $5 \mathrm{~min}$.

The melting curve was recorded at $60^{\circ} \mathrm{C}$. The primers used are shown in Table 2 . The amplification efficiency of each gene was validated by drawing a standard curve through four serial dilutions of cDNA. For analyses, relative quantification was applied with $\beta$-actin considered as the internal control. A bird sample chosen from control group was used as the internal sample. Protocols were done in triplicate. The relative mRNA expression levels of CARNS, CNDP2, PHT1, PEPT1, PEPT2, and HDC were calculated using the $\Delta \triangle C_{\mathrm{t}}$ method, followed by Primers for RT PCR analysis [17,18].

Table 2. Primers used in qPCR analysis in broiler chicks.

\begin{tabular}{ccccc}
\hline Genes & Forward Primer $\left(\mathbf{5}^{\prime}-\mathbf{3}^{\prime}\right)$ & Reserve Primer $\left(\mathbf{3}^{\prime}-\mathbf{5}^{\prime}\right)$ & $\mathbf{T}_{\mathbf{m}}\left({ }^{\circ} \mathbf{C}\right)$ & $\mathbf{G e n e ~ I D ~}^{\prime}$ \\
\hline CARNS & CTGGAGGGGTCAGCAAGAG & CTGTCGTAGGGCAGGAAGGT & 62 & 100359387 \\
CNDP2 & CACCTCACCTTCTGGCTTGT & ACATGCTTCCCTCTTCTCCA & 62 & 421013 \\
PEPT1 & TGTCACTGGGCTGGAGTTT & AGCAAGGCAGCAAAGAGAAC & 60 & 378789 \\
PEPT2 & GTGGGGTTCAGACATGGAAG & GGCCAGACCTGTAATGGAGA & 62 & 424244 \\
PHT1 & CTGGCAGAGGACAAACACAA & ACTCGCTGCACTCAATTTCC & 60 & 416808 \\
HDC & GGCAGGCTCTTCCTTATTCC & GCAGTGCGTTGAATGATGTT & 62 & 425454 \\
$\beta$-actin & TGACAATGGCTCCGGTATGT & TCTTTCTGGCCCATACCAAC & 60 & 396526 \\
\hline
\end{tabular}

Note: CARNS, carnosine synthase; CNDP2, carnosinase-2; PEPT1/PEPT2, proton-coupled oligopeptide transporters; PHT1 carnosine/histidine transporters; $H D C$, histidine decarboxylase.

\subsection{Statistical Analysis}

The normality of the data and the homogeneity of variances were tested in SPSS 16.0 for Windows (SPSS Inc., Chicago, IL, USA); the interactions between L-histidine and beta-alanine were analyzed with covariance analysis using the generalized linear models (GLM) of SPSS software. Then, the statistical significance of comparisons between the means of L-histidine and beta-alanine was further assessed using covariance analysis, as the interaction between the L-histidine and beta-alanine was not significant. The treatment effects were considered significant at $p<0.05$, whereas a trend for a treatment effect was noted at $0.05<p<0.10$.

\section{Results}

\subsection{Growth Performance}

The effect of dietary L-histidine and beta-alanine on growth performance is listed in Table 3. BW, ADFI, ADG, and FCR were not influenced by dietary beta-alanine supplementation throughout the entire period $(p>0.05)$. Dietary L-histidine addition markedly decreased ADG $(p<0.01)$, whereas it tended to reduce BW $(0.05<p<0.1)$ and improve FCR $(0.05<p<0.1)$ during the starter period (days 1 to 21$)$. No notable differences in growth performance were found among all L-histidine treatments during the growth period (days 22 to $42, p>0.05$ ) and the entire period (days 1 to $42, p>0.05$ ). However, no significant differences were observed in response to the interaction of L-histidine and beta-alanine throughout the trial $(p>0.05)$. 
Table 3. Effect of dietary L-histidine and beta-alanine supplementation on growth performance in broiler chicks ${ }^{1}$.

\begin{tabular}{|c|c|c|c|c|c|c|c|c|c|c|c|c|c|}
\hline \multirow{2}{*}{$\begin{array}{l}\text { L-histidine } \\
\text { (mg/kg) }\end{array}$} & \multirow{2}{*}{\multicolumn{2}{|c|}{$\begin{array}{l}\text { Beta-alanine } \\
\text { (mg/kg) }\end{array}$}} & BW & ADFI & ADG & FCR & BW & ADFI & ADG & FCR & ADFI & ADG & FCR \\
\hline & & & \multicolumn{4}{|c|}{ 1-21 Days } & \multicolumn{4}{|c|}{ 22-42 Days } & \multicolumn{3}{|c|}{ 1-42 Days } \\
\hline 0 & \multicolumn{2}{|c|}{0} & 819.66 & 53.52 & 37.71 & 1.42 & 2411.86 & 146.26 & 75.87 & 1.94 & 90.32 & 52.81 & 1.71 \\
\hline 0 & \multicolumn{2}{|c|}{1200} & 848.57 & 53.23 & 39.07 & 1.40 & 2562.31 & 150.97 & 79.18 & 1.91 & 92.59 & 52.99 & 1.68 \\
\hline 650 & \multicolumn{2}{|c|}{0} & 843.37 & 54.61 & 38.88 & 1.41 & 2416.83 & 148.21 & 73.27 & 2.04 & 92.87 & 52.92 & 1.76 \\
\hline 650 & \multicolumn{2}{|c|}{1200} & 825.00 & 53.91 & 37.86 & 1.45 & 2510.90 & 147.24 & 78.73 & 1.87 & 92.08 & 54.13 & 1.70 \\
\hline 1300 & \multicolumn{2}{|c|}{0} & 809.61 & 54.27 & 36.93 & 1.47 & 2429.88 & 143.93 & 73.58 & 1.96 & 90.88 & 51.77 & 1.75 \\
\hline 1300 & \multicolumn{2}{|c|}{1200} & 801.53 & 53.51 & 35.99 & 1.46 & 2391.71 & 141.65 & 71.75 & 1.98 & 87.59 & 50.13 & 1.75 \\
\hline 1950 & \multicolumn{2}{|c|}{0} & 815.89 & 53.28 & 37.51 & 1.42 & 2553.80 & 146.97 & 78.61 & 1.88 & 91.98 & 54.41 & 1.69 \\
\hline 1950 & \multicolumn{2}{|c|}{1200} & 786.40 & 52.26 & 34.69 & 1.52 & 2438.17 & 138.10 & 73.94 & 1.89 & 86.29 & 50.14 & 1.72 \\
\hline \multicolumn{3}{|c|}{ Pooled SEM } & 5.860 & 0.475 & 0.332 & 0.010 & 25.497 & 1.353 & 1.076 & 0.017 & 0.858 & 0.523 & 0.009 \\
\hline \multicolumn{3}{|c|}{ Source } & \multicolumn{11}{|c|}{$p$-value } \\
\hline \multicolumn{3}{|c|}{ L-histidine } & 0.085 & 0.708 & 0.024 & 0.076 & 0.642 & 0.252 & 0.432 & 0.279 & 0.430 & 0.353 & 0.119 \\
\hline \multicolumn{3}{|c|}{ Beta-alanine } & 0.567 & 0.469 & 0.204 & 0.129 & 0.658 & 0.497 & 0.794 & 0.214 & 0.279 & 0.285 & 0.355 \\
\hline \multicolumn{3}{|c|}{ L-histidine $\times$ beta-alanine } & 0.330 & 0.995 & 0.185 & 0.135 & 0.247 & 0.373 & 0.332 & 0.197 & 0.404 & 0.277 & 0.365 \\
\hline \multirow{6}{*}{$\begin{array}{l}\text { Main } \\
\text { Effect }\end{array}$} & & 0 & 834.11 & 53.38 & $38.39^{a}$ & 1.41 & 2487.09 & 148.62 & 77.52 & 1.93 & 91.46 & 52.9 & 1.69 \\
\hline & & 650 & 834.19 & 54.26 & $38.37^{\mathrm{a}}$ & 1.43 & 2463.87 & 147.73 & 76.00 & 1.96 & 92.48 & 53.52 & 1.73 \\
\hline & dine & 1300 & 805.57 & 53.89 & $36.46^{\mathrm{ab}}$ & 1.47 & 2410.79 & 142.79 & 72.67 & 1.97 & 89.24 & 50.95 & 1.75 \\
\hline & & 1950 & 801.15 & 52.77 & $36.10^{b}$ & 1.47 & 2495.99 & 142.54 & 76.28 & 1.89 & 89.14 & 52.27 & 1.71 \\
\hline & & 0 & 822.13 & 53.92 & 37.76 & 1.43 & 2453.09 & 146.34 & 75.33 & 1.96 & 91.51 & 52.97 & 1.73 \\
\hline & inine & 1200 & 815.38 & 53.23 & 36.90 & 1.46 & 2475.77 & 144.49 & 75.90 & 1.91 & 89.64 & 51.85 & 1.71 \\
\hline
\end{tabular}

${ }^{1} n=8$ replicates per treatment. ADG (g/day) = average daily gain; ADFI (g/day) = average daily feed intake; FCR (feed $/$ gain = g:g) = feed conversion ratio; $\mathrm{BW}(\mathrm{g})=$ body weight. ${ }^{\mathrm{a}, \mathrm{b}}$ Means in a column lacking a common superscript letter differ significantly $(p<0.05)$.

\subsection{Meat Quality}

The effect of dietary L-histidine and beta-alanine on meat quality is shown in Table 4. At $45 \mathrm{~min}$ postmortem, dietary L-histidine supplementation at $1300 \mathrm{mg} / \mathrm{kg}$ or $1950 \mathrm{mg} / \mathrm{kg}$ significantly decreased $\mathrm{a}^{*}$ and $\mathrm{b}^{*}$ values $(p<0.05)$. Moreover, dietary supplementation of $1950 \mathrm{mg} / \mathrm{kg}$ L-histidine increased the $\mathrm{pH}_{45 \mathrm{~min}}$ and $\mathrm{b}_{24}{ }_{2}$ h value of breast muscle $(p<0.05)$. However, the $L^{*}$ value at $45 \mathrm{~min}$ or $24 \mathrm{~h}$ did not vary in response to dietary L-histidine addition $(p>0.05)$. Furthermore, dietary beta-alanine supplementation significantly increased the $\Delta \mathrm{pH}$ value $(p<0.05)$. Furthermore, the interaction of L-histidine and beta-alanine significantly decreased the $\mathrm{L}^{*} 45 \mathrm{~min}$ value and increased the $\Delta \mathrm{pH}_{24 \mathrm{~h}}$ and $\mathrm{a}_{24} \mathrm{~h}$ values of breast muscle in the current study $(p<0.05)$. However, no notable differences were observed in shear force, drip loss, and cooking loss in response to either L-histidine or beta-alanine supplementation in the diet $(p>0.05)$.

Table 4. Effects of dietary L-histidine and beta-alanine on meat quality of broiler chicks at day $42^{1}$.

\begin{tabular}{|c|c|c|c|c|c|c|c|c|c|c|c|c|c|c|}
\hline \multirow{2}{*}{$\begin{array}{l}\text { L-histidine } \\
\text { (mg/kg) }\end{array}$} & \multirow{2}{*}{\multicolumn{2}{|c|}{$\begin{array}{l}\text { Beta-alanine } \\
\quad(\mathrm{mg} / \mathrm{kg})\end{array}$}} & $\mathbf{L}$ & a & $\mathbf{b}$ & $\mathrm{pH}$ & $\mathbf{L}$ & a & $\mathbf{b}$ & $\mathrm{pH}$ & $\triangle \mathbf{p H}$ & \multirow{2}{*}{$\begin{array}{l}\text { Shear } \\
\text { Force }\end{array}$} & \multirow{2}{*}{$\begin{array}{l}\text { Drip } \\
\text { Loss }\end{array}$} & \multirow{2}{*}{$\begin{array}{l}\text { Cooking } \\
\text { Loss }\end{array}$} \\
\hline & & & \multicolumn{4}{|c|}{$45 \mathrm{~min}$} & \multicolumn{5}{|c|}{$24 \mathrm{~h}$} & & & \\
\hline 0 & \multicolumn{2}{|c|}{0} & 49.49 & 8.35 & 16.11 & 6.13 & 56.97 & 8.21 & 11.58 & 5.72 & 0.41 & 17.45 & 5.75 & 8.04 \\
\hline 0 & \multicolumn{2}{|c|}{1200} & 52.00 & 9.85 & 16.10 & 6.29 & 58.72 & 7.89 & 12.23 & 5.77 & 0.59 & 16.87 & 5.60 & 8.17 \\
\hline 650 & \multicolumn{2}{|c|}{0} & 53.58 & 8.12 & 14.18 & 6.19 & 58.64 & 7.31 & 11.88 & 5.89 & 0.30 & 19.17 & 5.21 & 8.59 \\
\hline 650 & \multicolumn{2}{|c|}{1200} & 51.20 & 7.73 & 15.47 & 6.35 & 58.60 & 7.98 & 11.98 & 5.77 & 0.58 & 18.27 & 7.23 & 8.51 \\
\hline 1300 & \multicolumn{2}{|c|}{0} & 49.85 & 6.02 & 14.33 & 6.36 & 56.54 & 7.76 & 11.94 & 5.85 & 0.50 & 20.58 & 6.88 & 8.68 \\
\hline 1300 & \multicolumn{2}{|c|}{1200} & 49.48 & 6.41 & 11.61 & 6.27 & 55.97 & 8.18 & 12.04 & 5.83 & 0.43 & 20.57 & 5.79 & 8.29 \\
\hline 1950 & \multicolumn{2}{|c|}{0} & 49.55 & 6.13 & 14.03 & 6.31 & 56.00 & 8.15 & 13.23 & 5.89 & 0.48 & 21.46 & 5.52 & 8.52 \\
\hline 1950 & \multicolumn{2}{|c|}{1200} & 50.56 & 5.60 & 13.49 & 6.32 & 58.26 & 8.03 & 13.46 & 5.84 & 0.48 & 18.29 & 3.80 & 7.91 \\
\hline \multicolumn{3}{|c|}{ Pooled SEM } & 0.244 & 0.013 & 0.302 & 0.016 & 0.317 & 0.052 & 0.160 & 0.012 & 0.018 & 0.644 & 0.335 & 0.067 \\
\hline \multicolumn{3}{|c|}{ Source } & \multicolumn{12}{|c|}{$p$-value } \\
\hline \multirow{3}{*}{\multicolumn{3}{|c|}{$\begin{array}{c}\text { L-histidine } \\
\text { Beta-alanine } \\
\text { L-histidine } x \text { beta-alanine }\end{array}$}} & 0.001 & $<0.001$ & 0.004 & 0.095 & 0.065 & 0.016 & 0.005 & 0.005 & 0.760 & 0.348 & 0.066 & 0.602 \\
\hline & & & 0.691 & 0.433 & 0.419 & 0.058 & 0.186 & 0.127 & 0.400 & 0.144 & 0.010 & 0.412 & 0.633 & 0.374 \\
\hline & & & 0.007 & 0.086 & 0.138 & 0.021 & 0.331 & 0.004 & 0.917 & 0.089 & 0.005 & 0.872 & 0.054 & 0.768 \\
\hline \multirow{6}{*}{$\begin{array}{l}\text { Main } \\
\text { effect }\end{array}$} & & 0 & $50.74^{\mathrm{ab}}$ & $9.10^{\mathrm{a}}$ & $16.10^{a}$ & 6.21 & 57.85 & $8.05^{a}$ & $11.90^{\mathrm{b}}$ & $5.75^{\mathrm{b}}$ & 0.50 & 17.09 & 5.67 & 8.11 \\
\hline & & 650 & $52.39^{a}$ & $7.92^{b}$ & $14.83^{\mathrm{ab}}$ & 6.27 & 58.62 & $7.65^{b}$ & $11.93^{b}$ & $5.83^{a b}$ & 0.44 & 18.72 & 6.08 & 8.54 \\
\hline & dine & 1300 & $49.67^{\mathrm{b}}$ & $6.22^{c}$ & $12.97^{b}$ & 6.31 & 56.25 & $7.97^{\mathrm{ab}}$ & $11.99^{b}$ & $5.84^{\mathrm{a}}$ & 0.47 & 20.58 & 6.37 & 8.51 \\
\hline & & 1950 & $50.06^{b}$ & $5.87^{\mathrm{c}}$ & $13.76^{\mathrm{b}}$ & 6.32 & 57.13 & $8.09^{a}$ & $13.35^{\mathrm{a}}$ & $5.86^{\mathrm{a}}$ & 0.48 & 19.35 & 4.66 & 8.25 \\
\hline & & 0 & 50.62 & 7.16 & 14.66 & 6.25 & 57.04 & 7.86 & 12.16 & 5.84 & $0.42 * *$ & 19.55 & 5.84 & 8.52 \\
\hline & & 1200 & 50.81 & 7.40 & 14.17 & 6.31 & 57.89 & 8.02 & 12.43 & 5.80 & $0.52 *$ & 18.19 & 5.49 & 8.24 \\
\hline
\end{tabular}

${ }^{1} n=8$ replicates per treatment. ${ }^{\text {a-c }}$ Means in a column lacking a common superscript letter differ significantly $(p<0.05) .{ }^{*}, *$ Means in a column lacking a common superscript differ significantly $(p<0.05)$. 


\subsection{Antioxidant Indices in Breast Muscle and Plasma}

The effects of dietary L-histidine and beta-alanine on antioxidant parameters (T-AOC, MDA, and T-SOD) in breast meat and plasma are illustrated in Table 5. Compared to the control, T-AOC and T-SOD activity in all L-histidine treatments and the interaction of L-histidine and beta-alanine groups was significantly increased both in breast meat and in plasma at day $42(p<0.05)$. Dietary beta-alanine supplementation elevated T-AOC in breast meat compared with the control group $(p<0.05)$. MDA concentrations were markedly decreased in all supplemental groups in breast meat $(p<0.05)$ and only in the beta-alanine treatment groups in plasma $(p<0.05)$.

Table 5. Effect of dietary L-histidine and beta-alanine on antioxidant parameters in breast muscle and plasma of broiler chicks at day $42^{1}$.

\begin{tabular}{|c|c|c|c|c|c|c|c|c|}
\hline \multirow{2}{*}{$\begin{array}{l}\text { L-histidine } \\
\text { (mg/kg) }\end{array}$} & \multirow{2}{*}{\multicolumn{2}{|c|}{ Beta-alanine (mg/kg) }} & \multicolumn{3}{|c|}{ Breast } & \multicolumn{3}{|c|}{ Plasma } \\
\hline & & & T-AOC & MDA & T-SOD & T-AOC & MDA & T-SOD \\
\hline 0 & \multicolumn{2}{|r|}{0} & 0.22 & 0.92 & 45.94 & 3.55 & 2.26 & 149.48 \\
\hline 0 & \multicolumn{2}{|r|}{1200} & 0.30 & 0.70 & 49.48 & 3.92 & 2.12 & 169.86 \\
\hline 650 & \multicolumn{2}{|r|}{0} & 0.26 & 0.75 & 48.71 & 3.62 & 2.22 & 177.87 \\
\hline 650 & \multicolumn{2}{|r|}{1200} & 0.26 & 0.76 & 45.31 & 4.93 & 2.10 & 167.61 \\
\hline 1300 & \multicolumn{2}{|r|}{0} & 0.28 & 0.72 & 49.17 & 4.99 & 2.28 & 177.30 \\
\hline 1300 & \multicolumn{2}{|r|}{1200} & 0.32 & 0.69 & 47.07 & 6.20 & 2.15 & 186.17 \\
\hline 1950 & \multicolumn{2}{|r|}{0} & 0.29 & 0.60 & 51.37 & 5.63 & 2.28 & 206.40 \\
\hline 1950 & \multicolumn{2}{|r|}{1200} & 0.26 & 0.64 & 51.26 & 4.67 & 2.23 & 158.79 \\
\hline \multicolumn{3}{|c|}{ Pooled SEM } & 0.005 & 0.008 & 0.335 & 0.127 & 0.017 & 2.343 \\
\hline \multicolumn{3}{|c|}{ Source } & \multicolumn{6}{|c|}{$p$-value } \\
\hline \multicolumn{3}{|c|}{ L-histidine } & 0.010 & $<0.001$ & $<0.001$ & $<0.001$ & 0.253 & 0.004 \\
\hline \multicolumn{3}{|c|}{ Beta-alanine } & 0.024 & 0.003 & 0.444 & 0.063 & 0.002 & 0.133 \\
\hline \multicolumn{3}{|c|}{ L-histidine $\times$ beta-alanine } & 0.001 & 0.003 & 0.004 & 0.009 & 0.708 & $<0.001$ \\
\hline \multirow{6}{*}{$\begin{array}{l}\text { Main } \\
\text { effect }\end{array}$} & \multirow{4}{*}{ dine } & 0 & $0.26^{\mathrm{b}}$ & $0.81^{\mathrm{a}}$ & $47.71^{\mathrm{b}}$ & $3.74^{\mathrm{c}}$ & 2.19 & $159.67^{b}$ \\
\hline & & 650 & $0.26^{\mathrm{b}}$ & $0.75^{b}$ & $47.01^{\mathrm{b}}$ & $4.28^{b c}$ & 2.16 & $172.74^{\mathrm{a}}$ \\
\hline & & 1300 & $0.30^{\mathrm{a}}$ & $0.71^{\mathrm{b}}$ & $48.12^{b}$ & $5.59^{\mathrm{a}}$ & 2.22 & $181.74^{\mathrm{a}}$ \\
\hline & & 1950 & $0.28^{\mathrm{ab}}$ & $0.62^{c}$ & $51.31^{\mathrm{a}}$ & $5.15^{\mathrm{ab}}$ & 2.25 & $182.59^{a}$ \\
\hline & \multirow{2}{*}{ Beta-alanine } & 0 & $0.26^{* *}$ & 0.75 * & 48.80 & 4.45 & $2.26 *$ & 177.76 \\
\hline & & 1200 & $0.29 *$ & $0.70^{* *}$ & 48.28 & 4.93 & $2.15^{* *}$ & 170.61 \\
\hline
\end{tabular}

\subsection{Dipeptide Content in Breast and Gene Expression of Carnosine Synthesis-Related Enzymes}

The effects of dietary L-histidine and beta-alanine on carnosine, anserine, and dipeptide are indicated in Figure 1. The contents of carnosine and anserine were significantly increased in all L-histidine-containing treatments at day $42(p<0.05)$, especially in the $1300 \mathrm{mg} / \mathrm{kg}$ L-histidine $+1200 \mathrm{mg} / \mathrm{kg}$ beta-alanine group. Moreover, dietary beta-alanine significantly increased the carnosine concentration $(p<0.05)$ and tended to increase the anserine levels $(0.05<p<0.1)$. However, no significant difference was observed in dipeptide in response to beta-alanine supplementation in the diets $(p>0.05)$. 


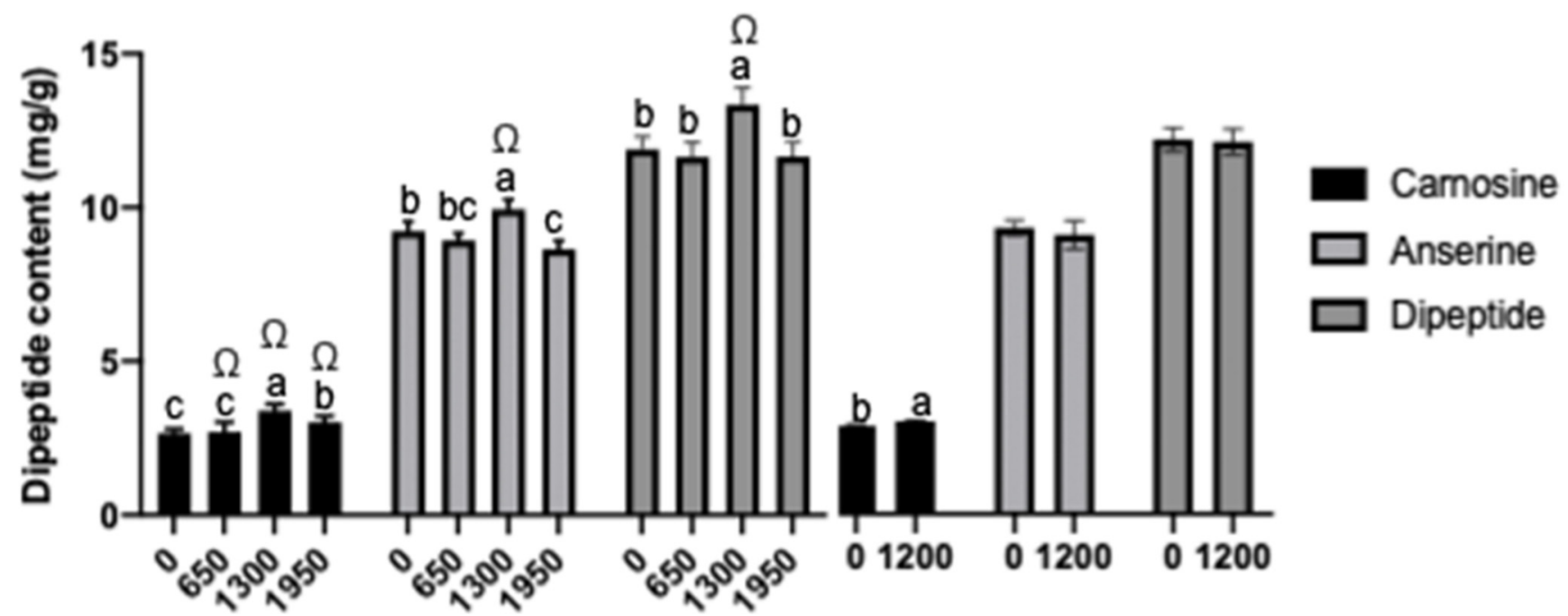

L-histidine ( $\mathrm{mg} / \mathbf{k g})$

Beta-alanine $(\mathrm{mg} / \mathrm{kg})$

Figure 1. Effects of dietary L-histidine and beta-alanine on content of carnosine and anserine in broiler chicks at day $42^{1} .{ }^{1}$ $n=8$ replicates per treatment. ${ }^{\mathrm{a}-\mathrm{c}}$ Means in a column lacking a common superscript differ significantly $(p<0.05){ }^{\Omega}$ Means in a column lacking a common superscript differ significantly (interaction of L-histidine and beta-alanine) $(p<0.05)$.

Table 6 shows the mRNA expression of HDC, PHT1, PEPT1, PEPT2, CNDP1, and CARNS in breast muscle. Dietary L-histidine supplementation significantly increased the expression of HDC, PEPT1, and CARNS $(p<0.05)$ and tended to improve the mRNA expression of $P H T 1$ in breast muscle $(0.05<p<0.1)$. Furthermore, the mRNA expression of $C A R N S$ was improved in response to beta-alanine supplementation $(p<0.05)$. However, only the expression of PHT1 was improved by the interaction of L-histidine and beta-alanine in breast muscle $(p<0.05)$.

Table 6. Effects of dietary L-histidine and beta-alanine on mRNA expression of carnosine synthesis-related enzymes in broiler chicks ${ }^{1}$.

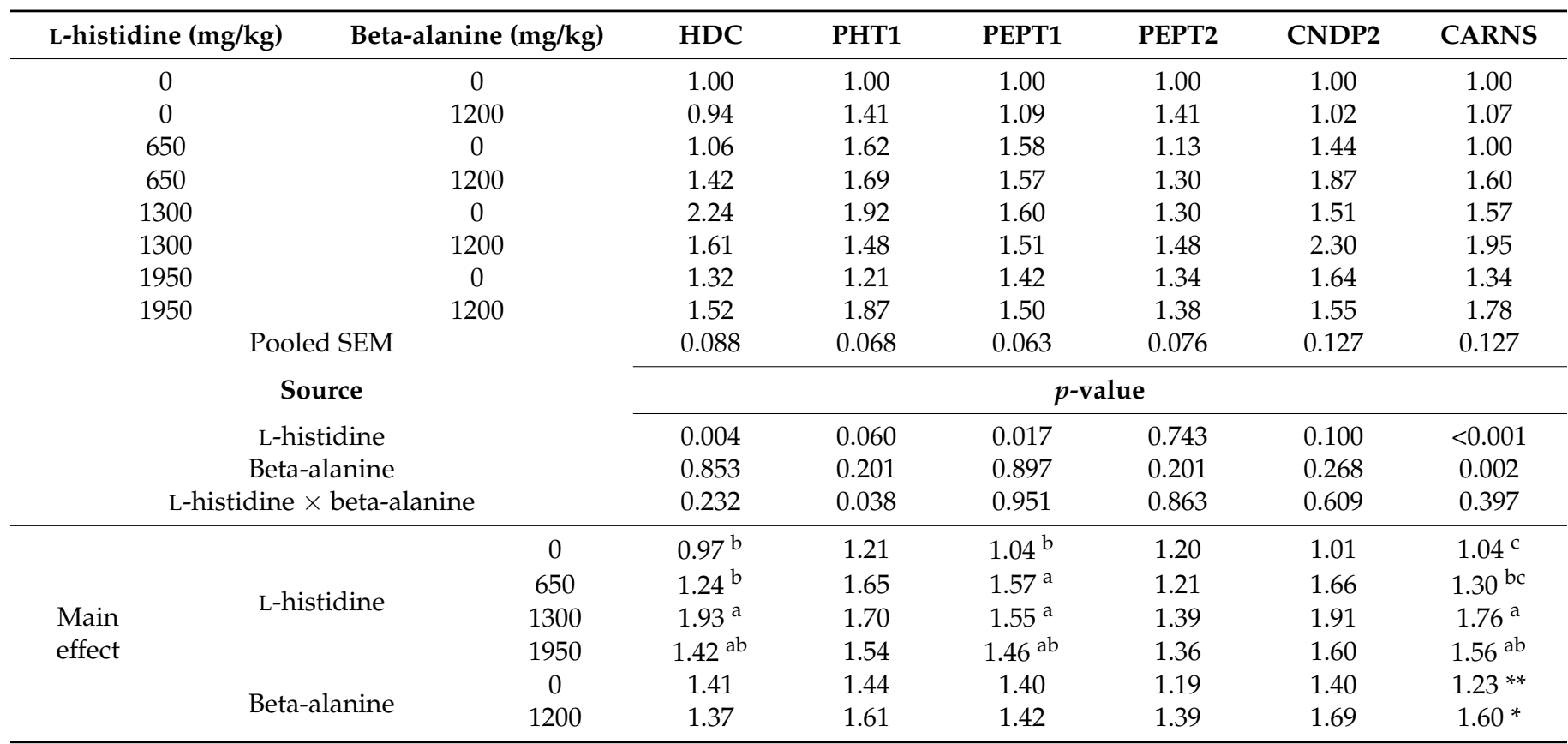

${ }^{1} n=8$ replicates per treatment. CARNS, carnosine synthase; CNDP2, carnosinase-2; PEPT1/PEPT2, proton-coupled oligopeptide transporters; PHT1 carnosine/histidine transporters; HDC, histidine decarboxylase. ${ }^{\text {a-c }}$ Means in a column lacking a common superscript differ significantly $(p<0.05) .{ }^{*},{ }^{* *}$ Means in a column lacking a common superscript differ significantly $(p<0.05)$. 


\section{Discussion}

Dietary L-histidine supplementation decreased the growth performance throughout the entire experimental period. These results are consistent with a previous study [19]. In the current study, chickens fed diets containing L-histidine from 650 to $1950 \mathrm{mg} / \mathrm{kg}(0.065 \%$ to $0.195 \%$ ) significantly reduced the ADG, improved the FCR, and tended to decrease the body weight during the starter growth period. Supplementation with $0.3 \%$ L-histidine in the diet reduced the body weight, ADG, and ADFI by $13.6 \%, 13.6 \%$, and $10.5 \%$, respectively, during the period of 10 to 28 days [20]. However, there was no effect on body weight and FCR in response to $0.18 \%$ L-histidine supplementation at day 42 in turkey [21]. At the same time, there was no significant influence in response to beta-alanine supplementation. Some similar results were obtained from studies with the addition of beta-alanine in chickens [13], mice [6], and pigs [22].

In the current study, diets supplemented with L-histidine reduced feed efficiency by decreasing ADG. A possible reason is that L-histidine is purported to be toxic in high supplementation dosages $(2000 \mathrm{mg} / \mathrm{kg}$ BW per day) and has demonstrated retarded growth rates and hypercholesterolemia [23,24]. In addition, L-histidine could influence body weight through its conversion into neuronal histamine, which could suppress the food intake or appetite [25]. This concept is supported by an earlier study, which revealed that chickens depress growth in response to an increase in histamine [26].

Meat quality is used to describe the properties and perception of meat, and good meat quality can improve consumers' acceptance of meat products. The meat color is a consequence of physiological, biochemical, and microbiological changes in muscles and is an important parameter related to muscle $\mathrm{pH}$ [27]. In the present study, supplementation with $1950 \mathrm{mg} / \mathrm{kg}$ histidine significantly decreased the $\mathrm{a}^{*}$ value and $\mathrm{b}^{*}$ value at $45 \mathrm{~min}$ postmortem, yet it increased the $\mathrm{pH}$ value at $24 \mathrm{~h}$ postmortem. Meanwhile, beta-alanine alone or combined with L-histidine supplementation markedly increased the $\mathrm{pH}_{45}$ min and $\Delta \mathrm{pH}_{24} \mathrm{~h}$ values at day 42 . A previous study reported that the breast muscle had a lower degree of a* value in response to histidine supplementation in diets [11], which is similar to our result. The possible reason may be related to changes in histamine content. Poultry meat with high $\mathrm{pH}$ has been associated with high water-binding capacity and subsequently improved meat quality [28]. Meat color varies because of the different concentrations of pigments; one of the principal pigments in poultry is hemoglobin [29], and the level of hemoglobin was shown to have a positive connection with histamine [30].

The values of shear force, drip loss, and cooking loss in breast muscle were not affected by dietary L-histidine or / and beta-alanine supplementation in broilers [11], which is similar to the current study. However, dietary supplementation with 200 or $400 \mathrm{mg} / \mathrm{kg}$ carnosine significantly decreased the shear force of breast in broilers because carnosine could inhibit the process of lipid peroxidation. The latter could cause $\mathrm{Ca}^{2+}$ pump uncoupling and Ca-ATPase inactivation, leading to an increase in $\mathrm{Ca}^{2+}$ levels and a reduction in shear force value [31]. Moreover, muscles at $\mathrm{pH} \geq 6.0$ are characterized by lower protein denaturation, whereas muscles at $\mathrm{pH} \leq 6.0$ undergo greater protein denaturation [30]. In the present study, the increased $\mathrm{pH}$ or $\Delta \mathrm{pH}$ in all treatments implied that beta-alanine and/or Lhistidine may slow down protein denaturation. Meanwhile, carnosine is a functional dipeptide found in high concentrations in skeletal muscle [3] and is considered a potent buffer due to the pKa of its imidazole ring (6.83) [32]. The concentration of carnosine was markedly increased in breast muscle in response to all treatments in the current study, which would help to improve meat quality.

In the present study, dietary L-histidine addition significantly elevated the T-AOC and SOD contents both in muscle and in plasma, whereas it decreased the MDA content in breast muscle, especially in the $1300 \mathrm{mg} / \mathrm{kg}$ L-histidine $+1200 \mathrm{mg} / \mathrm{kg}$ beta-alanine group. These results are similar to a previous study [33], which reported that dietary histidine increased the activity of SOD of broilers both in breast muscle and in plasma. L-Histidine demonstrates strong antioxidant characteristics and may react with free radicals and the 
carbonylation of proteins in the body to resist oxidation or the action of metal ions that promote the activity of oxidase [34].

Furthermore, dietary supplementation of carnosine increased the activity of T-AOC, yet it decreased the MDA content in breast muscle in broilers at day 42 [35]. It was reported that beta-alanine had a lower level of thiobarbituric acid reactive substances (mg MDA $/ \mathrm{kg}$ of tissue) than the control group [36]. Moreover, the interaction of L-histidine and betaalanine decreased MDA in breast muscle and increased T-AOC and T-SOD both in breast muscle and in plasma. The improved antioxidant abilities may result from the increased concentration of carnosine, which has a strong antioxidant capacity [31,37]. Therefore, the combination of $1300 \mathrm{mg} / \mathrm{kg}$ L-histidine and $1200 \mathrm{mg} / \mathrm{kg}$ beta-alanine led to superior muscle antioxidant ability in the current study.

Carnosine is synthesized from two precursors (L-histidine and beta-alanine) via carnosine synthase [38]. Anserine is a methylated form of carnosine, which was found at high levels in the muscles of salmon and tuna, which are migratory fish [39]. In the present study, supplementation with $1300 \mathrm{mg} / \mathrm{kg}(0.13 \%)$ L-histidine significantly enhanced the concentration of carnosine and anserine (31.6\% and $6.75 \%$, respectively), which is similar to previous studies showing that the content of carnosine and anserine increased $(64 \%$ and $10 \%$, respectively) in response to $0.1 \%$ L-histidine supplementation in breast muscle in broilers [20] and that dietary supplementation with $0.18 \%$ L-histidine increased carnosine and anserine by $35.24 \%$ and $23.33 \%$, respectively [32]. Moreover, dietary beta-alanine or combinative supplementation with L-histidine markedly increased carnosine content in breast muscle; these results corroborate a previous finding that $1.2 \%$ beta-alanine or $1.8 \%$ carnosine supplementation significantly increased carnosine concentration in soleus in mice [6]. Several studies revealed that dietary beta-alanine supplementation could influence the concentration of histidine [40,41], which may lead to imbalance in the process of carnosine production and influence the carnosine levels; however, beta-alanine and histidine were not detected in breast muscle in the current results, which necessitates further study.

Furthermore, the gene expression of the enzymes and transporters related to carnosine synthesis were explored in skeletal muscle (CARNS, CNDP2, PEPT1, PEPT2, PHT1, and $H D C)$; only the mRNA expression of CARNS, PEPT1, and HDC was significantly upregulated in response to L-histidine and beta-alanine supplementation in the current study. It is expected that the synthesis of carnosine would be limited by the expression of CARNS [42], whereas the upregulation of CARNS gene could promote the accumulation of carnosine in breast muscle in broilers [6]. PEPT1 can transport both L-histidine and carnosine in skeletal muscle [6]; hence, competition for transporter PEPT1 may exist between histidine and carnosine. Dietary addition of L-histidine stimulates the expression of HDC, which is an enzyme responsible for the decarboxylation of histidine to produce histamine [43]. Histamine may potentially negatively affect body weight (as mentioned earlier). However, the elevation of $H D C$ expression implies that the possibility of carnosine degradation to histidine and subsequent decarboxylation inside the skeletal muscle cell may occur. Therefore, carnosine levels in skeletal muscle increased through complicated interactions among CARNS, PEPT1, and HDC.

\section{Conclusions}

Dietary addition of L-histidine and beta-alanine could improve meat quality by increasing T-AOC and carnosine content and decreasing MDA level in breast muscle. The increase in muscular carnosine content was likely due to the upregulation of mRNA expression of carnosine synthesis-related enzymes and transporters (CARNS, PEPT1, and $H D C$ ) in broilers following 42 days of dietary L-histidine and beta-alanine supplementation. Moreover, the interaction of $1300 \mathrm{mg} / \mathrm{kg}$ L-histidine and $1200 \mathrm{mg} / \mathrm{kg}$ beta-alanine improved the meat quality, antioxidant capacity, and carnosine levels in the breast muscle of broilers with no adverse effects on growth performance. 
Author Contributions: Conceptualization, B.Q., H.Z., and G.Q.; methodology, H.Z., S.W., J.W., and Y.M.; data curation, B.Q., Y.M., and M.H.; resources, H.Z. and G.Q.; writing-original draft preparation, H.Z., S.W., and M.H.; writing-review and editing, B.Q., K.Q., and H.Z; supervision, H.Z.; project administration, H.Z. and G.Q. All authors read and agreed to the published version of the manuscript.

Funding: This study was financed by the Shandong Key Science and Technology Innovation Program (2019JZZY010704), the National Key R\&D Program of China (2018YFD0500403), the Beijing Innovation Consortium of Agriculture Research System, and the Agricultural Science and Technology Innovation Program (ASTIP) of the Chinese Academy of Agricultural Sciences.

Institutional Review Board Statement: The study was conducted according to the guidelines of the Declaration of Helsinki, and approved by the Ethic Committee of Feed research Institute (Protocol code: AEC-CAAS-20191118).

Informed Consent Statement: Not applicable.

Data Availability Statement: None of the data were deposited in an official repository. This is an open access article. Anyone who needs to see raw data could email me (bo.qi@live.vu.edu.au).

Conflicts of Interest: The authors declare no conflict of interest.

\section{References}

1. Monteverde, V.; Congiu, F.; Vazzana, I.; Dara, S.; Dipietro, S.; Piccione, G. Serum lipid profile modification related to polyunsaturated fatty acid supplementation in thoroughbred horses. J. Appl. Anim. Sci. 2017, 45, 615-618. [CrossRef]

2. Piccione, G.; Giannetto, C.; Bruschetta, D.; Congiu, F.; Arfuso, F.; Giudice, E. Influence of exercise and dietary omega-3 oil supplementation on interleukin 1-Ra serum concentrations in Standardbred horses. Anim. Prod. Sci. 2019, 59, 232-235. [CrossRef]

3. Guiotto, A.; Calderan, A.; Ruzza, P.; Borin, G. Carnosine and carnosine-related antioxidants: A review. Curr. Med. Chem. 2005, 12, 2293. [CrossRef] [PubMed]

4. Boldyrev, A.A.; Severin, S.E. The histidine-containing dipeptides, carnosine and anserine: Distribution, properties and biological significance. Adv. Enzym. Regul. 1990, 30, 175-188. [CrossRef]

5. Schön, M.; Mousa, A.; Berk, M.; Chia, W.L.; Ukropec, J.; Majid, A.; Ukropcová, B. De Courten, B. The potential of carnosine in brain-related disorders: A comprehensive review of current evidence. Nutrients 2019, 11, 1196. [CrossRef]

6. Everaert, I.; De Naeyer, H.; Taes, Y.; Derave, W. Gene expression of carnosine-related enzymes and transporters in skeletal muscle. Eur. J. Appl. Physiol. 2013, 113, 1169-1179. [CrossRef] [PubMed]

7. Tomonaga, S.; Kaji, Y.; Tachibana, T.; Denbow, D.M.; Furuse, M. Oral administration of $\beta$-alanine modifies carnosine concentrations in the muscles and brains of chickens. Anim. Sci. J. 2005, 76, 249-254. [CrossRef]

8. Tomonaga, S.; Kaneko, K.; Kaji, Y.; Kido, Y.; Denbow, D.M.; Furuse, M. Dietary $\beta$-alanine enhances brain, but not muscle, carnosine and anserine concentrations in broilers. Anim. Sci. J. 2006, 77, 79-86. [CrossRef]

9. Boldyrev, A.A. Carnosine and Oxidative Stress in Cells and Tissue, 4th ed.; Nova Science Publishers Inc.: New York, NY, USA, 2006.

10. Harris, R.C.; Wise, J.A.; Price, K.A.; Kim, H.J.; Kim, C.K.; Sale, C. Determinants of muscle carnosine content. Amino Acids 2012, 43, 5-12. [CrossRef] [PubMed]

11. Kralik, G.; Kralik, Z.; Djurkin Kušec, I.; Škrtić, Z.; Kralik, I. Effect of dietary histidine, hybrid line and gender on chicken meat quality and concentration of carnosine. Poult. Sci. 2015, 52, 295-303. [CrossRef]

12. Tomonaga, S.; Matsumoto, M.; Furuse, M. $\beta$-Alanine enhances brain and muscle carnosine levels in broiler chicks. Poul. Sci. 2012, 49, 308-312. [CrossRef]

13. Park, S.W.; Kim, C.H.; Namgung, N.; Jung, B.Y.; Paik, I.K.; Kil, D.Y. Effects of dietary supplementation of histidine, $\beta$-alanine, magnesium oxide, and blood meal on carnosine and anserine concentrations of broiler breast meat. Poult. Sci. 2013, 50, 251-256. [CrossRef]

14. Qi, B.; Wang, J.; Ma, Y.B.; Wu, S.G.; Qi, G.H.; Zhang, H.J. Effect of dietary $\beta$-alanine supplementation on growth performance, meat quality, carnosine content, and gene expression of carnosine-related enzymes in broilers. Poult. Sci. 2018, 97, 1220-1228. [CrossRef]

15. Aviagen. Arbor Acres Broiler Management Guide; Aviagen Inc.: Huntsville, AL, USA, 2009.

16. Zhang, L.; Yue, H.Y.; Zhang, H.J.; Xu, L.; Wu, S.G.; Yan, H.J.; Gong, Y.S.; Qi, G.H. Transport stress in broilers: I. Blood metabolism, glycolytic potential, and meat quality. Poult. Sci. 2009, 88, 2033-2041. [CrossRef]

17. Derveaux, S.; Vandesompele, J.; Hellemans, J. How to do successful gene expression analysis using real-time PCR. Methods 2010, 50, 227-230. [CrossRef]

18. Xue, C.; Li, Y.; Lv, H.; Zhang, L.; Bi, C.; Dong, N.; Shan, A.; Wang, J. Oleanolic Acid Targets the Gut-Liver Axis to Alleviate Metabolic Disorders and Hepatic Steatosis. J. Agric. Food Chem. 2021. [CrossRef]

19. Kai, S.; Watanabe, G.; Kubota, M.; Kadowaki, M.; Fujimura, S. Effect of dietary histidine on contents of carnosine and anserine in muscles of broilers. Anim. Sci. J. 2015, 86, 541-546. [CrossRef] 
20. Haug, A.; Rodbotten, R.; Mydland, L.T.; Christophersen, O.A. Increased broiler muscle carnosine and anserine following histidine supplementation of commercial broiler feed concentrate. Acta Agr. Scand. A 2008, 58, 71-77. [CrossRef]

21. Kopec, W.; Wiliczkiewicz, A.; Jamroz, D.; Biazik, E.; Pudlo, A.; Hikawczuk, T.; Skiba, T.; Korzeniowska, M. Antioxidant status of turkey breast meat and blood after feeding a diet enriched with histidine. Poult. Sci. 2016, 95, 53-61. [CrossRef]

22. Mei, L.; Cromwell, G.L.; Crum, A.D.; Decker, E.A. Influence of dietary $\beta$-alanine and histidine on the oxidative stability of pork. Meat Sci. 1998, 49, 55-64. [CrossRef]

23. Hitomi-Ohmura, E.; Amano, N.; Aoyama, Y.; Yoshida, A. The effect of a histidine-excess diet on cholesterol synthesis and degradation in rats. Lipids 1992, 27, 755-760. [CrossRef]

24. Solomon, J.K.; Geison, R.L. Effect of excess dietary L-histidine on plasma cholesterol levels in weanling rats. J. Nutr. 1978, 108, 936-943. [CrossRef]

25. Yoshimatsu, H.; Chiba, S.; Tajima, D.; Akehi, Y.; Sakata, T. Histidine suppresses food intake through its conversion into neuronal histamine. Exp. Biol. Med. 2002, 227, 63-68. [CrossRef]

26. Harry, E.G.; Tucker, J.F. The effect of orally administered histamine on the weight gain and development of gizzard lesions in chicks. Vet. Rec. 1976, 99, 206-207. [CrossRef]

27. Baker, R.C.; Bruce, C.A. Further processing of poultry. In Processing of Poultry, 4th ed.; Springer: Boston, MA, USA, 1995; pp. 251-282.

28. Barbut, S. Estimates and detection of the PSE problem in young turkey breast meat. Can. J. Anim. Sci 1996, 76, 455-457. [CrossRef]

29. Santiago, H.L. Biological, Nutritional, and Processing Factors Affecting Breast Meat Quality of Broilers. Ph.D. Thesis, Virginia Polytechnic Institute and State University, Virginia, VA, USA, 2002.

30. Jochem, J. Haematological, blood gas and acid-base effects of central histamine-induced reversal of critical haemorrhagic hypotension in rats. J. Physiol. Pharmacol. 2001, 52, 447-458.

31. Cong, J.; Zhang, L.; Li, J.; Wang, S.; Gao, F.; Zhou, G. Effects of dietary supplementation with carnosine on growth performance, meat quality, antioxidant capacity and muscle fiber characteristics in broiler chickens. J. Sci. Food Agric. 2017, 97, 3733-3741. [CrossRef]

32. Harris, R.C.; Marlin, D.J.; Dunnett, M.; Snow, D.H.; Hultman, E. Muscle buffering capacity and dipeptide content in the thoroughbred horse, greyhound dog and man. Comp. Biochem. Physiol. A. 1990, 97, 249-251. [CrossRef]

33. Kopeć, W.; Jamroz, D.; Wiliczkiewicz, A.; Biazik, E.; Pudlo, A.; Hikawczuk, T.; Skiba, T.; Korzeniowska, M. Influence of different histidine sources and zinc supplementation of broiler diets on dipeptide content and antioxidant status of blood and meat. Br. Poult. Sci. 2013, 54, 454-465. [CrossRef] [PubMed]

34. Wade, A.M.; Tucker, H.N. Antioxidant characteristics of L-histidine. J. Nutr. Biochem. 1998, 9, 308-315. [CrossRef]

35. Hu, X.; Hongtrakul, K.; Ji, C.; Ma, Q.; Guan, S.; Song, C.; Zhang, Y.; Zhao, L. Effect of carnosine on growth performance, carcass characteristics, meat quality and oxidative stability in broiler chickens. Poult. Sci. 2009, 46, 296-302. [CrossRef]

36. Kralik, G.; Sak-Bosnar, M.; Kralik, Z.; Galović, O. Effects of $\beta$-alanine dietary supplementation on concentration of carnosine and quality of broiler muscle tissue. Poult. Sci. 2014, 51, 151-156. [CrossRef]

37. Boldyrev, A.; Bulygina, E.; Leinsoo, T.; Petrushanko, I.; Tsubone, S.; Abe, H. Protection of neuronal cells against reactive oxygen species by carnosine and related compounds. Comp. Biochem. Physiol. Part B Biochem. Mol. Biol. 2004, 137, 81-88. [CrossRef]

38. Stenesh, J.J.; Winnick, T. Carnosine-anserine synthetase of muscle. 4. Partial purification of the enzyme and further studies of $\beta$-alanyl peptide synthesis. Biochem. J. 1960, 77, 575-581. [CrossRef]

39. Jones, N.R. The free amino acids of fish. 1-Methylhistidine and $\beta$-alanine liberation by skeletal muscle anserinase of codling (Gadus callarias). Biochem. J. 1955, 60, 81-87. [CrossRef]

40. Blancquaert, L.; Everaert, I.; Missinne, M.; Baguet, A.; Stegen, S.; Volkaert, A.; Petrovic, M.; Vervaet, C.; Achten, E.; De Maeyer, M.; et al. Effects of histidine and $\beta$-alanine supplementation on human muscle carnosine storage. Med. Sci. Sports Exerc. 2017, 49, 602-609. [CrossRef]

41. Saunders, B.; de Salles Painelli, V.; De Oliveira, L.F.; da Eira Silva, V.; Da Silva, R.P.; Riani, L.; Franchi, M.; Goncalves, L.D.; Harris, R.C.; Roschel, H.; et al. Twenty-four weeks of $\beta$-alanine supplementation on carnosine content, related genes, and exercise. Med. Sci. Sports Exerc. 2017, 49, 896-906. [CrossRef]

42. Drozak, J.; Veiga-da-Cunha, M.; Vertommen, D.; Stroobant, V.; Van Schaftingen, E. Molecular identification of carnosine synthase as ATP-grasp domain-containing protein 1 (ATPGD1). J. Biol. Chem. 2010, 285, 9346-9356. [CrossRef]

43. Haas, H.L.; Sergeeva, O.A.; Selbach, O. Histamine in the nervous system. Physiol. Rev. 2008, 88, 1183-1241. [CrossRef] 